\title{
Record of Animals Association with Xanthostemon novoguineensis (Valeton)
}

\author{
RAYNARD C. SANITO \\ Department of Environmental Engineering, University of Science Technology Jayapura, Jayapura, Papua \\ Diterima: 9 Juli 2018 - Disetujui: 15 Agustus 2018 \\ (C) 2018 Jurusan Biologi FMIPA Universitas Cenderawasih
}

\begin{abstract}
Xanthostemon novoguineenis (vernacular name: Sowang), an endemic plant in Papua from Myrtaceae family, is found widely near the buffer zone area and Mt. Cyclops Nature Reserve (MCNR) area. This research aimed to record the association of animals towards X. novoguineensis on its natural habitat. The survey was conducted in Cyclops buffer zone near Sentani City, Papua Province, Indonesia. The result showed that an interaction of animals directly to $X$. novoguineensis was documented and identified. Some insects species have an association with $X$. novoguineensis, namely black wasp (Isodontia sp 1), black-orange wasp (Isodontia sp 2), red weaver ant (Oecophylla sp 1) and black weaver ant (Oecophylla sp 2) have an association directly to flowers of X. novoguineensis. Furthermore, stick insect (Scepthrophasma sp) and spider (possibly from Araneae family) have an association with the leaves and trunks of this plant. Based on the finding, some leaves of these plant are fed by insects. It is indicated by a pattern of insect bites on the leaves.
\end{abstract}

Key words: buffer zone area, cyclops, insect, sowang, Papua.

\section{INTRODUCTION}

$X$. novoguineensis, which is also known widely with the vernacular name "Sowang" by Sentani Tribes, is one of Xanthostemon species that has been reported as an endemic species from Papua (Wilujeng \& Simbiak, 2015). This plant is classified into Myrtaceae family. The distribution of this plant predominantly is near buffer zone of Cyclops Natural Reserve Conservation Area and Sentani Lake (Wilujeng \& Simbiak; Sanito, 2016). Furthermore, this plant may be found widely in dry land habitat (Sanito, 2018). According to Modouw (2006), Wilujeng \& Simbiak (2015), Sanito (2016), this plant may be found widely near

\footnotetext{
* Alamat korespondensi:

Department of Environmental Engineering, University of Science Technology Jayapura, Jayapura, Papua, Indonesia. Jl. Raya Padang Bulan, Waena, Abepura. E-mail: raynardsanito@gmail.com
}

Waibu District, Doyo Lama District, Heram District, and Tobati District, in Jayapura Regency. Sanito \& Keiluhu (2017) find that this plant growth naturally on the Cenderawasih University campus area, Kamp Walker, particularly on the university forest. It means that distribution of this plant spread widely in the buffer area of Cyclops Nature Reserve Conservation Area.

According to Wilujeng \& Simbiak (2015), the wood structure of $X$. novoguineensis is harsh and durable. Therefore, the wood of this plant has been used widely by Sentani Tribes to support their life since long time ago. Mainly, the function of the wood represents social and cultural aspects of Sentani Tribes in various purposes (Modouw, 2006: Mumbo, 2010; Wilujeng \& Simbiak, 2015; Sanito, 2016; Sanito, 2017; Sanito, 2018a; Sanito, 2018b). In ethnobotany perspective, Sentani ethnics usually use the wood of this plant for several purposes such as produce utensils (Mumbo, 2010; Sanito, 2017), agriculture equip- 
ment, represent the status of chief village (Sanito, 2017), weapon, pillars of house (Mumbo, 2010), raw material of traditional boat (Sanito, 2018b), and dowry (Modouw, 2006). Based on these aspects, it can be clearly understood that this plant is essential for sustainable life of Sentani Ethnic.

Xanthostemon species has a huge potential to be applied widely in phytotechnology aspects (Sanito, 2018a). It means this plant can be cultivated widely in the open green space area to provide a nursery ground for some animals. Ling \& Hui (2016): Singh \& Wee (2006) report that some bird species feed the fruits and nectars of $X$. chrysanthus in Singapore. In addition, Nazaruddin (2017) states that X. chrysanthus has been applied widely in the urban area in Malaysia. Although $X$. novoguineensis has not applied widely in this context, the enormous potential requires further investigation due to assess this opportunity in Papua (Sanito, 2018a).

The population of $X$. novoguineensis de-creased significantly in Cyclops Mountainous Conservation Area, harder to find the tree form and susceptible to an endangered species (Simbiak \& Wilujeng, 2015). As Simbiak \& Wilujeng (2015) point out, the habitat fragmentation, deforestation, exceeding the use of wood, and regeneration of the plant itself are believed as the main factors that contributed to this situation. İt will become a huge loss if this plant is truly extinct prior to the association of animals toward this plant is not investigated accurately.

Despite ethnobotany aspects and phytotechnology aspects have been investigated as an aforementioned, ecology aspects of $X$. novoguineensis has a lack of information. In ecology perspective, plants are necessary due to their role to provide a source of food to animals, nursery ground, and function in the environment (Silva \& Pinheiro, 2009; Sanito \& Keiluhu, 2017). Previous research has been reported that animals such as ants and crickets have an association with this plant (Yawan, 2007). However, more information of the parts of the plant is not determined clearly. In addition, the previous research by Yawan (2007), is merely conducted at the Buper Area, Heram District. In other words, it requires further investigation to find more information related to its association.

Insects have a vital role in pollination systems. Silva \& Pinheiro (2009) state that insects are the pollinators of the Myrtaceae family, especially Eugenia genus. Then, pollination process may provide the fruit production of the plant. Goulson (1999) point out that generally, insects have an important role in the pollination of the flowers. Furthermore, the nectars usually are fed by insects as a source of food. Based on this context, as well as the other species, $X$. novoguineensis that has the attractive flowers, potentially provides the food source of insects and has an association with pollinator insects.

The purpose of this research is to record the association among animals and X. novoguineensis in their natural habitat. It also provides information on ecology potential of this plant in Papua. The association among animals and this plant are being discussed and described in this paper.

\section{METHODS}

The survey was conducted on Cyclops Nature Reserve Area, Sentani City, Jayapura in December 2017. Then, animals that have an association with this plant, were documented using DLSR camera (Canon EOS $700 \mathrm{D})$ with a combination of $70 \mathrm{~mm}-$ $135 \mathrm{~mm}$ lens (Canon).

Identification of animals was identified to species degree. However, the animals, which could not be identified to the species levels due to the lack of literature reference, was only identified into its family or order. Then, recording of survey data was analyzed qualitatively.

\section{RESULTS AND DISCUSSION}

\section{Association of Animals}

Several animals were found directly dominated by insects that associated naturally with $X$. novoguineensis, namely black wasp (Hymenoptera), red ant and black ant 
Table 1. The list of animals that have an association with X. novoguineensis.

\begin{tabular}{clll}
\hline No & Name of Animals & \multicolumn{1}{c}{ Family } & \multicolumn{1}{c}{ Finding } \\
\hline 1 & Black Wasp & Sphecidae & Absorb nectar on the flowers \\
2 & Black - Orange Wasp & Sphecidae & Absorb nectar on the flowers \\
2 & Red Weaver Ant & Formicidae & Absorb nectar on the flowers \\
3 & Black Weaver Ant & Formicidae & Absorb nectar on the flowers \\
4 & Stick Insect & Phasmatidae & Attached on the trunks and leaves \\
5 & Grasshopper & Orthoptera & Found near the habitat \\
6 & Spider & Araneae (order) & Attached on the trunks \\
7 & Butterfly & Lycaenidae & Found near the habitat \\
\hline
\end{tabular}

(Formicidae), stick insects (Phasmatodea) and spider. Then, grasshopper (Orthoptera) and butterfly (Lycaenidae) also were found at on surrounding the plant (Table 1).

\section{Association of Animals Towards Flowers of $X$. novoguineenis.}

Exploration was conducted based on the exploration in the field, there are four animals that have an association directly with the flowers. All of the animals namely black wasp (Isodontia sp 1), black-orange wasp (Isodontia sp 2), red weaver ant (Oecophylla sp 1) and black weaver ant (Oecophylla sp 2). All of these animals absorbs the nectars of the flowers. Then, It can be clearly understood that it provides the source of food for the insects (fig 1).

Some plants also often are found in the field as the food source of butterflies and bees. Plants such as blue porterweed (Stachytarpheta jamaicensis), white porterweed (Stachytarpheta indica) and red porterweed (Stachytarpheta sp) are well known as the source food of this animal (Van Mastright \& Rosariyanto, 2005). On this location, Mussaenda sp and orchid (Spathoglotis plicata) may be found regularly on this habitat. Then, based on this context, $X$. novoguineenis also provides a food for wasp. Indeed, wasp has a various source of food, especially the nectars of flowers. As well as wasp, the flowers of this plant also provide the food for black ant and red ant. Kuriakose et al. (2018) point out that mostly the flower of Myrtaceae species is visited regularly by whitefooted ants (Technomyres albipes) and red weaver ant (Oecophylla samaragdina). As Kuriakose et al.
(2018) show, Technomyres albipes and Oecophylla samaragdina are the pollinator for Syzygium occidentale. Indeed, ants are founded regularly on the flowers of this plant. As a comparison, it is possible to assume that the flowers of $X$. novoguneensis provide a source of food for the ants and wasps. Also, probably these insects play an important role in pollination of $X$. novoguineensis.

According to Shuttleworth \& Johnson (2009); Wiemar et al. (2012), wasps have a vital role in an ecosystem of the environment such as controls caterpillar on the environment and pollination of flowers. In the pollination process, pistils that attached to the wasps body often be transferred to the other flowers (pistillium). Then, the pollination process occurs and it aids the sustainable of the plant itself. Menz et al. (2015) report that wasps often visited Agonis flexusa and Eucalyptus marginata (Myrtaceae). Interestingly, it has been proven that many pollens attached to the body of wasps. Then, Chauhan et al. (2017) report that many insects, birds and mammals visited the flowers of Callistemon citrinus (Myrtaceae) for foraging nectars, aiding the cross-pollination and inter-tree pollination. Butterflies, ants, wasps, bees, sunbirds, parrots, moth, hover flies, oriental white-eye sparrow and squirrels are examples. Interestingly, wasps foraging only for nectar and an occasional pollinator for plants. In addition, Shuttleworth \& Johnson (2009) claim that open wide flowers with unprotected nectar usually caused an attraction towards various insects. Indeed, the plant has particular pollination systems. In this result, it may be assumed that the 


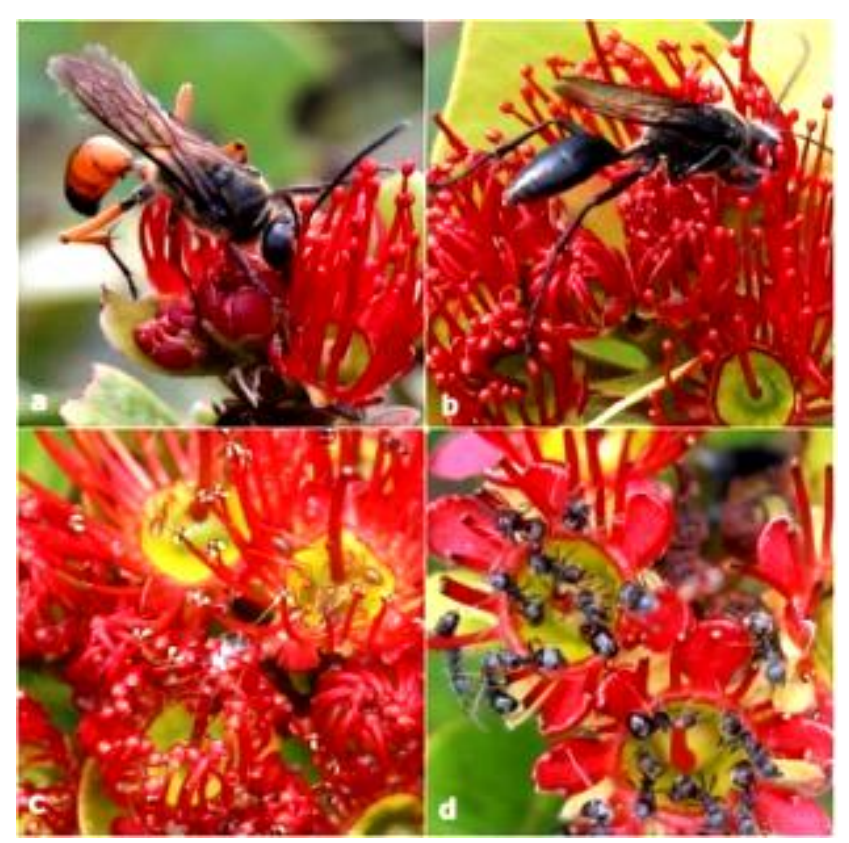

Figure 1. Evidence of an association directly between insects and the flower of $X$. novoguineensis (a) \& (b) the documentation of wasp that absorb the nectar at the flower of $X$. novoguineenis. (c). red ants, (d). black ants (Photograph: R.C. Sanito).

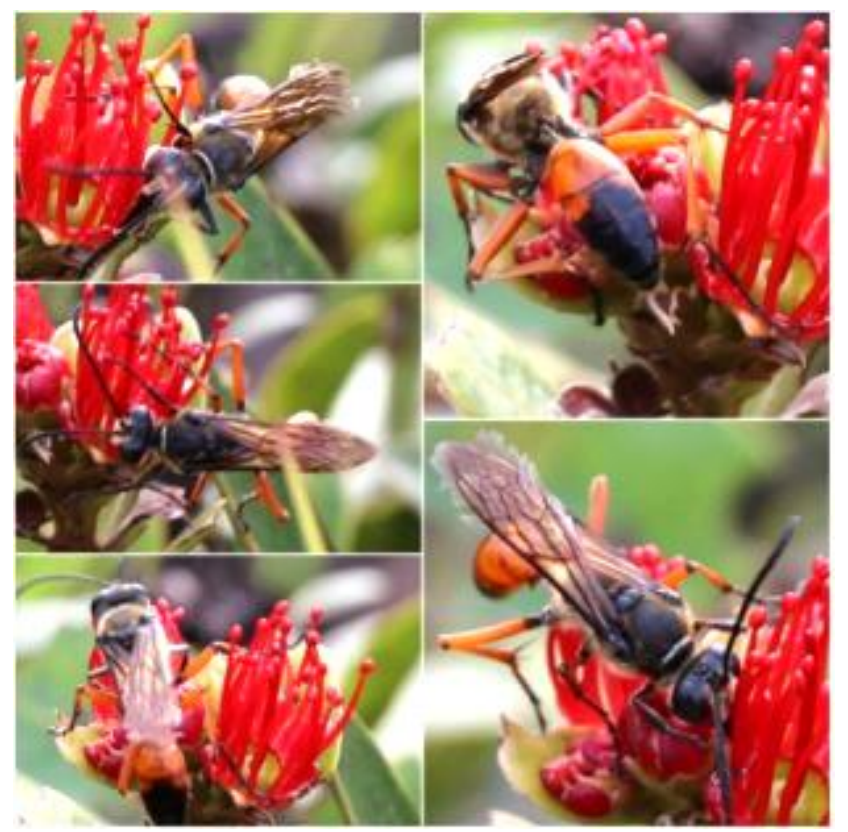

Figure 2. Movement of black-orange wasp in the absorption of nectar at the $X$. novoguineensis flowers. The images based on various angles and positions (Photograph: R.C. Sanito).

black wasp and orange wasp were attracted by the flower of $X$. novoguineensis (fig 2). This wasp visited the flowers of this plant regularly.
It is often believed that the flowers species of myrtaceae usually be visited by species of hymenoptera. Silva \& Pinheiro (2009), for instances, written that species of hymenoptera (Apis melifera) visited flowers of Myrtaceae family such as Eugenia uniflora, E. punicifolia, E. neonitida and $E$. rotundifolia as the main pollinators. Kuriakose et al. (2018) also report that Xylocopa sp also foraging nectar of $S$. occidantale. Silva \& Pinheiro (2009) also claim that some flowers from the Myrtaceae family have hermaphrodite, polystemonous, papaver type of pollen flowers and generalist characteristics. Due to the intra flowers movement, foraging behavior and as well as the other three species plants of Myrtaceae, wasp has an important role as the main pollinators of $X$. novoguineensis (fig 2). In this context, this insect absorbs nectars from flowers. Furthermore, Isodontia sp 2 also visited other $X$. novoguineensis at the same place.

Although birds were not be found directly during the exploration, the further research should be conducted to prove this hypothesis that birds have an association with flowers of $X$. novoguineensis. Report from Amar-Singh \& Wee (2011) stated that some birds such as Acroditheres javanicus, Phyconotus golavier, Anthereptes malacensis, Loricukus galgulus and Trichoglossus hematodus feed the nectar of $X$. chrysanthus flowers. Subsequently, Ling \& Hui (2016) show that the fruit of $X$. chrysanthus is fed naturally by a bird namely Psittacula alexandri. Zilko et al. (2017) also claim that Lorikeet bird ( $T$. hematodus) has contributions to the pollination system. Zilko et al. (2017) describe that many pollens are found generally in the tongue of this bird, particularly from Myrtaceae species. Hence, $X$, novoguineensis has an enormous potential as well as $X$. chrysanthus for providing a source of food to the birds in Papua. A further investigation about the ecological niche of birds in pollination system of this plant should be conducted (Sanito, 2018a).

\section{Association of Animals Towards Trunks and Leaves of $X$. novoguineenis}


Based on the exploration result, some insects were found on the several parts of $X$. novoguineensis. In this context, stick insects, from

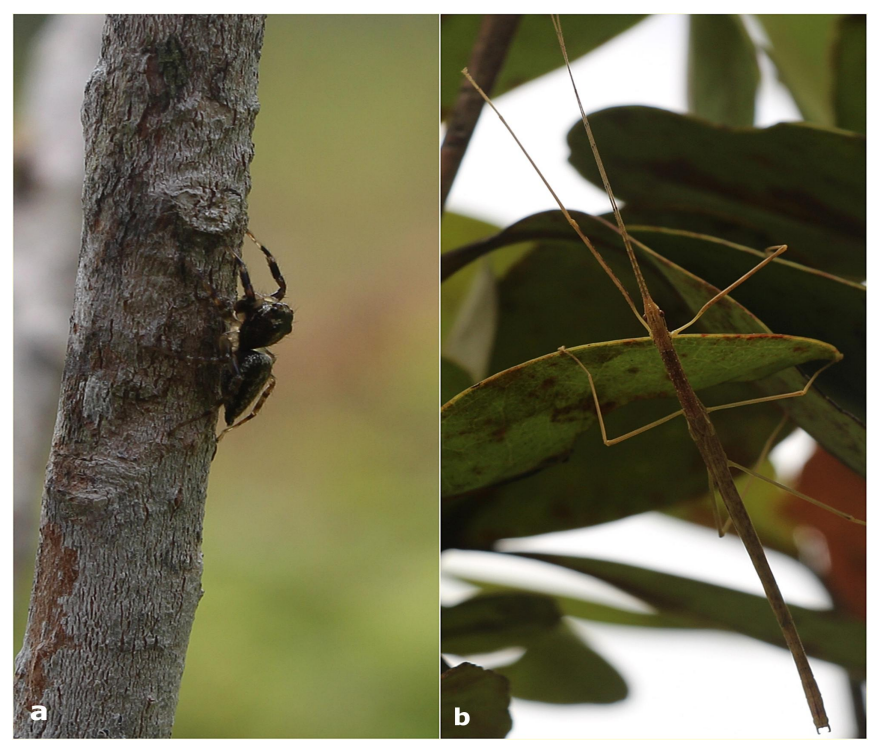

Figure 3. Evidence of direct associations between insects and the flower of $X$. novoguineensis. A photographed source in parentheses (a). Spider on the trunk (R.C. Sanito). (b) Stick insect on the leaves (R.C. Sanito).

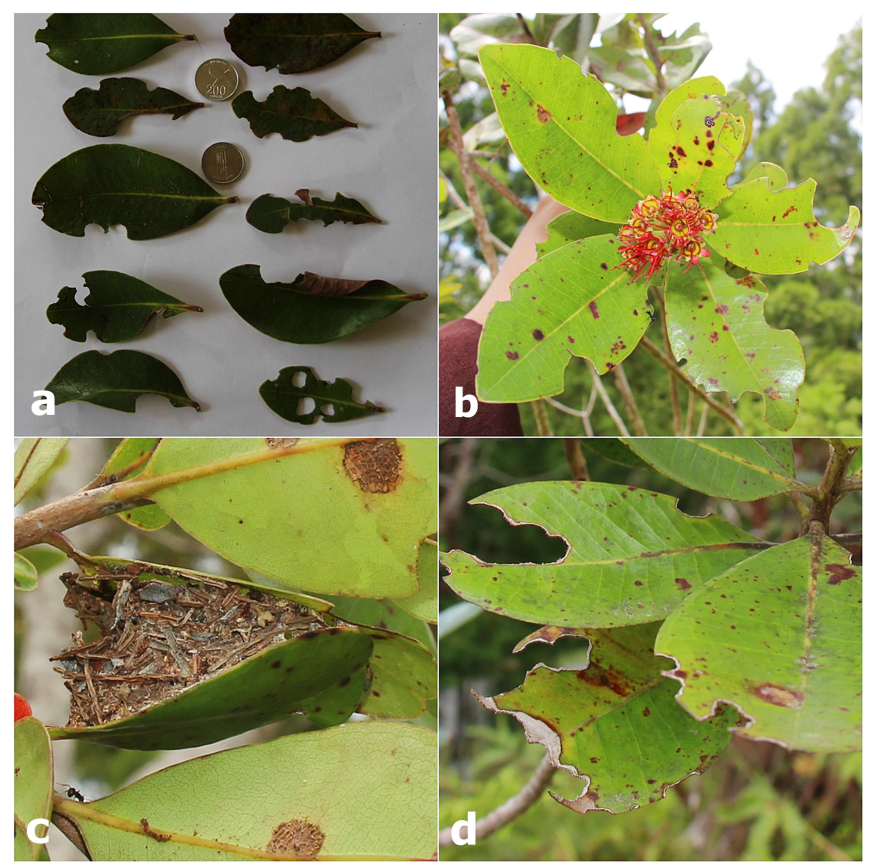

Figure 4. Evidence of direct associations between insects and the flower of $X$. novoguineensis. A photographed source in parentheses (a), (b), \& (d). Leaves of $X$. novoguineensis are fed by insect. The leaves have some patterns of Insect's bites. (R.C. Sanito). (c) Nest on the leaves of $X$. novoguineensis (R.C. Sanito).
Phasmatidae family, attached to the leaf (fig 3). The stick insects probably consumed the leaf of this plant. In fact, some leaves have formed of insect bites with a different pattern (fig 4). Based on this evidence, leave of this plant provides a source of food for insects.

Pakage (2010) reports that the leaves of Psidium guajava are fed by Anchiale maculate and Sosibia sp. These insects usually perches on this plant. Curtis (2011) reports that Eucalyptus sp is the source of food to the stick insects. In Australia, an amount of stick insects feeds fresh leaves of different species of Eucalyptus sp. In these contexts, the plants from Myrtaceae provides the main source of food to Stick Insects. Indeed, this plant has an important role as a nursery ground of Stick Insects. Based on the taxonomy context, P. guajava is a Myrtaceae family as well as X. novoguineensis. As well as P. guajava and Eucalyptus sp., leaves of $X$. novoguineensis probably also is a source of food to stick insects. The finding of stick insects at this plant probably for foraging, particularly at the leaf.

According to the exploration on the field, stick insects that refers resemble Sceptrophasma sp was found on the leaves. The availability of leaves predominantly supports the food source of this insect. As an evidence, some leaves, which were consumed directly by insects, were found widely on the plant. It is shown by bite pattern by insect on the edge of leaves (fig 4). According to the evidence in the field, it may be assumed that the leaves of $X$. novoguineensis was consumed by Scepthrophasma sp. However, further investigation is required to obtain a valid data and a new record of these aspects.

A spider (order: Araneae) also be found on the trunk of this plant. According to Uniyal \& Hore, (2008); Koneri \& Saroyo (2015), the presence of spider in an ecosystem depends on several environmental factors such as temperature, humidity, wind and light intensity. Samu et al., (2014) argue that spider has a vital role due to its contribution in food chain and forest biodiversity. An interaction between a spider and this plant is required further investigation due to the lack of information. The presence of spider in this plant may indicates that probably this plant has an 
essential role as ecological niche for spider. Subsequently, the finding of the nest between the leaves on this plant may emphasizing the role of $X$. novoguineesis in ecological niche. In fig 4 shows that the nest on the $X$. Novoguineensis leaves. However, it is still unknown what species that build the nest on this plant. Based on that finding, these plants may provide the suitable place to some species and sustain an ecological system in an environment.

\section{CONCLUSION}

Based on exploration result on the field, some insects namely wasps, weaver ant, stick insects, and spider are found that have an association with $X$. novoguineensis. Specifically, wasps and weaver ant have an association directly to the flowers of $X$. novoguineensis. The flowers of this plant provide the source of food these insects. In the context of insects as a pollinator, investigation of the main role of wasp as a pollinator to $X$. novoguineensis should be assessed clearly due to the lack of information.

In addition, Stick Insect and Spider, which are found on the leaves and trunks, respectively, probably foraging and the suitable place to life. Unfortunately, as well as wasps and weaver ants, an association of stick insects and spider in ecological perspectives requires a further investigation widely to obtain further information about the main role of this insect on the ecosystem and their niche.

Lastly, further research regarding identification of insects into the species level is essential. Papua has been recognized widely with the high biodiversity of insects. The investigation of the species may provide the information about species biodiversity in Papua.

\section{REFERENCES}

Amar-Singh, H.S.S., and Y.J. Wee. 2011. Golden penda (Xanthostemon chrysanthus) and nectar feeders. Bird Ecology Study Group. (online) (http:/ / www.besgroup.org/2011/03/30/golden-penda- xanthostemon-chrysanthus-and-nectar-feeders/), accessed 9 June 2018.

Chauhan, S., S.V.S. Chauhan., and L. Galetto. 2017. Floral and pollination biology, breeding system and nectar traits of Callistemon citrinus (Myrtaceae). South Africa Journal of Botany. 111: 319-325.

Curtis, S. 2011. Stick insects. Fact Sheet. Queensland Museum, Queensland Government. (Online) (http://www.qm. qld.gov.au/), accessed 5 July 2018.

Goulson, D. 1999. Foraging strategies of insects for gathering nectar and pollen and implications for plant ecology and evolution. Perspectives in Plant Ecology, Evolution and Systematics. 2(2): 185-209.

Menz, M.H.M., G.R. Brown., K.W. Dixon., and R.D. Phillips. 2015. Absence of nectar resource partitioning in a community of parasitoid wasps. J. Insect. Conservation. 99(4): 703-711.

Modouw, L.H. 2006. Struktur dan komposisi hutan pamah Pegunungan Cyclops, serta pemanfaatan kayu Xanthostemon spp oleh masyarakat etnis Sentani, Jayapura. [Tesis]. Universitas Indonesia. Depok.

Mumbo, E.M. 2010. Etnobotani kayu Sowang (Xanthosthemon sp) pada masyarakat Kampung Doyo Lama dan Kampung Harapan di Kawasan Cagar Alam Pegunugan Cyclops Kabupaten Jayapura. [Skripsi]. Universitas Cenderawasih, Jayapura.

Kuriakose, G., P.A. Sinu., and K.R. Shivanna. 2018. Ant pollination of Syzygium occidentale, an endemic tree species of tropical rain forests of Western Ghats, India. Arthropod-Plant Interactions. 12(5): 647-655.

Koneri, R., and Saroyo. 2015. Struktur komunitas laba-laba (Archnida: Araneae) di Taman Nasional Bogani Nani Wartabone, Sulawesi Utara. Jurnal Entomologi Indonesia. 12(3): 149-157.

Ling, K.L. and T.H., Hui. 2016. Red-breasted parakeets eating golden penda fruits. Singapore Biodiversity Records 168. ISSN 2345-7597.

Pakage, Y. 2010. Eksplorasi keragaman spesies belalang tongkat ordo phasmida di Cagar Alam Pegunungan Cyclops Jayapura. [Skripsi]. Universitas Cenderawasih, Jayapura, Papua.

Sanito, R.C. 2016. Analisis strategi konservasi Sowang (Xanthostemon sp) di sekitar Danau Sentani dan Cagar Alam Pegunungan Cyclops oleh Suku Sentani. Prosiding Seminar Ilmiah Hasil-hasil Penelitian Papua, Konferensi Internasional Keanekaragaman Hayati, Ekowisata dan Ekonomi Kreatif, Jayapura. Hal.: 149-159.

Sanito, R.C. 2017. Jenis-jenis tumbuhan lokal yang dimanfaatkan sebagai bahan baku pembuatan peralatan dalam pengolahan sagu (Metroxylon sp). Prosiding Seminar Nasional Pendidikan Biologi dan Saintek. Surakarta. 14-20. ISSN: 2527-5333X.

Sanito, R.C., and H.J. Keiluhu. 2017. Analisis strategi pembangunan arboretum di Universitas Cenderawasih sebagai upaya konservasi tumbuhan. Seminar Nasional Pendidikan Sains II. Hal.: 148-154.

Sanito, R.C. 2018a. Potensi tumbuhan Xanthostemon novoguineensis Valeton (Myrtaceae) dalam Fitoteknologi. Jurnal Biologi Papua. 10(1): 38-47. 
Sanito, R.C. 2018b. Jenis-jenis tumbuhan yang dimanfaatkan oleh suku sentani sebagai bahan baku pembuatan perahu tradisional. Prosiding Seminar Nasional Biologi dan Pendidikan Biologi 2018 UKSW. pp.: 112-117. ISBN: 978602-61913-1-1.

Samu, F., G. Lengyel., E. Szita., A. Bidlo and P. Odor. 2014. The effect of forest stand characteristics on spider diversity and species comsposition in derciduoudconiferus mixed forests. The Journal of Arachnology. 42: 135-141.

Silva, A.L.G., and M.C.B. Pinheiro. 2009. Reproductive success of four species of Eugenia L. (Myrtaceae). Act Bot. Bras. 23(2): 526-534.

Shuttleworth, A., and S.D. Johnson. 2009. The importance of scent and nectar filters in a specialized wasp-pollination system. Functional Ecology. (23): 931-940.

Wiemar, A.P., A.N. Serscici., S. Marino., A.O. Simo., and A.A. Cocucci. 2012. Functional morphology and wasp pollination of two South American Asclepiads (Asclepiadoideae-Apocynaceae). Annals of Botany. 109: 77-93.
Wilujeng, S and M. Simbiak. 2015. Karakterisasi morfologi Xanthostemon novoguineensis Valeton (Myrtaceae) dari Papua" Prosiding Seminar Nasional Masyarakat Biodiversitas Indonesia". 1(3): 466-471.

Uniyal V.P and U. Hore. 2008. Diversity and composition of spider assemblages in five vegetation types of the Terai Conservation Area, India. The Journal of Arachnology. 36: 251-258.

Van Mastright, H., and E. Rosariyanto. 2005. Buku panduan lapangan Kupu-kupu untuk wilayah Mamberamo dan sampai Pegunungan Cyclops. Conservation International Indonesia. Jakarta.

Yawan, E.C.N. 2007. Ekologi kayu sowang (Xanthostemon sp) di wilayah Waena Kampung Buper Kawasan Cagar Alam Cyclops Jayapura Papua. [Skkripsi]. Universitas Cenderawasih, Jayapura.

Zilko, J.P., S.E. Hoebee, and T.J. Edwards. 2017. Floral morphology of Eucalyptus leucoxylon (Myrtaceae) facilities pollination by lorikeet (Aves: Psittacidae) tongues. Australian Journal of Botany. 65: 368-374. 